\title{
Galectin-9 suppresses the tumor growth of colon cancer in vitro and in vivo
}

\author{
ASAHIRO MORISHITA ${ }^{1}$, KEI NOMURA ${ }^{1}$, JOJI TANI ${ }^{1}$, KOJI FUJITA ${ }^{1}$, HISAKAZU IWAMA ${ }^{2}$, KEI TAKUMA ${ }^{1}$, \\ MAI NAKAHARA ${ }^{1}$, TOMOKO TADOKORO ${ }^{1}$, KYOKO OURA $^{1}$, TAIGA CHIYO ${ }^{1}$, SHINTARO FUJIHARA ${ }^{1}$, \\ TOSHIRO NIKI ${ }^{3}$, MITSUOMI HIRASHIMA ${ }^{3}$, AKIRA NISHIYAMA ${ }^{4}$, TAKASHI HIMOTO ${ }^{5}$ and TSUTOMU MASAKI $^{1}$ \\ ${ }^{1}$ Department of Gastroenterology and Neurology, ${ }^{2}$ Life Science Research Center, \\ Departments of ${ }^{3}$ Immunology and Immunopathology, and ${ }^{4}$ Pharmacology, Kagawa University, Faculty of Medicine, \\ Miki-cho, Kita-gun, Kagawa 761-0793; ${ }^{5}$ Department of Medical Technology, \\ Kagawa Prefectural University of Health Sciences, Mure-cho, Takamatsu, Kagawa 761-0123, Japan
}

Received June 3, 2020; Accepted February 11, 2021

DOI: 10.3892/or.2021.8056

\begin{abstract}
Colon cancer is the second leading cause of cancer-related mortality worldwide, and the prognosis of advanced colon cancer has remained poor in recent years. Galectin-9 (Gal-9) is a tandem-repeat type galectin that has recently been shown to exert antiproliferative effects on various types of cancer cells. The present study aimed to assess the effects of Gal-9 on human colon and colorectal cancer cells in vitro and in vivo, as well as to evaluate the microRNAs (miRNAs/miRs) associated with the antitumor effects of Gal-9. We examined the ability of Gal-9 to inhibit cell proliferation via apoptosis, and the effects of Gal-9 on cell cycle-related molecules in various human colon and colorectal cancer cell lines. In addition, Gal-9-mediated changes in activated tyrosine kinase receptors and angiogenic molecules were assessed using protein array chips in colon and colorectal cancer cells. Moreover, miRNA array analysis was performed to examine Gal-9-induced miRNA expression profiles. We also elucidated if Gal-9 inhibited tumor growth in a murine in vivo model. We found that Gal-9 suppressed the cell proliferation of colon cancer cell lines in vitro and in vivo. Our data further revealed
\end{abstract}

Correspondence to: $\mathrm{Dr}$ Asahiro Morishita, Department of Gastroenterology and Neurology, Kagawa University, Faculty of Medicine, 1750-1 Ikenobe, Miki-cho, Kita-gun, Kagawa 761-0793, Japan E-mail: asahiro@med.kagawa-u.ac.jp

Abbreviations: CCK-18, caspase-cleaved keratin-18; CCK-8, Cell Counting Kit-8; CRC, colorectal cancer; CRD, carbohydrate-recognition domain; DMSO, dimethyl sulfoxide; ELISA, enzyme-linked immunosorbent; FBS, fetal bovine serum; Gal-9, galectin-9; IL-8, interleukin-8; miRNA/miR, microRNA; p-RTK, phosphorylated receptor tyrosine kinase; PBS, phosphate-buffered saline; TIMP-2, tissue inhibitor of metalloproteinases-2

Key words: colon cancer, galectin-9, apoptosis, microRNAs, caspase-cleaved keratin 18 that Gal-9 increased caspase-cleaved keratin 18 levels in Gal-9-treated colon cancer cells. In addition, Gal-9 enhanced the phosphorylation of ALK, DDR1, and EphA10 proteins. Furthermore, the miRNA expression levels, such as miR-1246, miR-15b-5p, and miR-1237, were markedly altered by Gal-9 treatment in vitro and in vivo. In conclusion, Gal-9 suppresses the cell proliferation of human colon cancer by inducing apoptosis, and these findings suggest that Gal-9 can be a potential therapeutic target in the treatment of colon cancer.

\section{Introduction}

Colorectal cancer (CRC) is the fourth most frequently diagnosed cancer in the world (1), and the prognosis of patients with advanced-stage CRC remains poor (2). Despite the advances in colon cancer treatment, especially in patients with non-metastatic colon cancer treated with curative intent by colectomy, no effective therapy has been demonstrated for patients with advanced stages of colon cancer (3-6). Considerations of disease stage and pathologic features, microsatellite instability status, possible efficacy and toxicity profiles of the chosen treatment, along with patient age, comorbidities, and personal preferences aid in the decision-making regarding the use of effective chemotherapy in patients with colon cancer (7-11). A better understanding of the mechanisms involved in colon cancer development and progression could improve the treatment outcomes in advanced-stage colon cancer. Thus, there is a strong demand for new effective therapeutic approaches for advanced stages of colon cancer.

Galectin-9 (Gal-9) belongs to the galectin protein family which is a subset of lectins with carbohydrate recognition domain (CRD) and subdivided into three groups: i) Prototype galectins (galectin-1, -2, -7, -10, -13, and -14), ii) chimera-type galectin (galectin-3), which have a single CRD, iii) and tandem-repeat type galectins (galectin-4, -8,-9, and -12), which have two CRDs joined by a flexible peptide linker (12-14). Gal-9 is known as a key molecule in eosinophil chemoattraction and activation (15-17) and exerts various other cellular functions, such as aggregation, adhesion, and apoptosis, in these 
cells $(18,19)$. Recent studies have demonstrated that Gal-9 may have antitumor effects in breast cancer (20-22), hepatocellular carcinoma $(23,24)$, and cholangiocarcinoma (25). In breast cancer, Gal-9 expression induced tumor cell aggregation and made tumor cells less aggressive, thus preventing metastasis and prolonging patient survival $(20,21)$. However, the role of Gal-9 in colon cancer remains unknown.

MicroRNAs (miRNAs) are small interfering, endogenous, noncoding RNAs that can modulate targeted protein expression by inhibiting translational efficiency or the cleavage of target mRNAs (6). Recently, aberrant miRNA expression has been detected in various human malignancies (9), and some reports have revealed that specific miRNAs are expressed in colon cancer (26). In addition, many studies, including our own, have reported that miRNAs play an important role in the antitumor effect of anticancer therapeutics $(9,11,12)$. However, the relationships between the anticancer effects of Gal-9 and miRNAs remain elusive.

Therefore, in the present study, we aimed to ascertain whether Gal-9 is effective in suppressing the proliferation of colon and colorectal cancer cells. Furthermore, we explored the underlying mechanisms, including activation of receptor tyrosine kinases, angiogenic profiles, and miRNA profiles associated with the antitumor effect of Gal-9.

\section{Materials and methods}

Reagents and chemicals. Recombinant stable and mutant forms of human Gal-9 lacking the entire linker region were expressed and purified as described in our previous report (27). Lactose, sucrose, and fetal bovine serum (FBS) were purchased from Wako Chemicals. Cell Counting Kit-8 (CCK-8) was purchased from Dojindo Laboratories, and all other chemicals were obtained from Sigma Chemical.

Cell lines and culture. The human colon cancer cell lines CACO-2, CW-2, COLO-320, LoVo, and the colorectal cancer cell line WiDr were obtained from the Japanese Cancer Research Resources Bank (Tokyo, Japan). All the cell lines were certified by STRA and mycoplasma testing was carried out for the cell lines used in our experiments. The cells were cultured in RPMI-1640 (Gibco; Invitrogen; Thermo Fisher Scientific, Inc.) supplemented with $10 \%$ heat-inactivated FBS, and penicillin-streptomycin $(100 \mu \mathrm{g} / \mathrm{ml}$; Invitrogen; Thermo Fisher Scientific, Inc.) in a humidified atmosphere with $5 \% \mathrm{CO}_{2}$ at $37^{\circ} \mathrm{C}$.

Cell proliferation assay. We performed cell proliferation assays using the CCK-8 assay according to the manufacturer's instructions. Each cell line ( $1 \times 10^{4}$ cells per well) was seeded into the wells of a 96-well plate and cultured in $100 \mu \mathrm{l}$ of RPMI-1640 medium supplemented with 10\% FBS. After incubation for $24 \mathrm{~h}$, the cells were treated with $0.01,0.03$, 0.10 , and $0.30 \mu \mathrm{M}$ of Gal-9 added to the culture medium and subsequently cultured for an additional $48 \mathrm{~h}$. Furthermore, $30 \mathrm{mM}$ of lactose was added to inhibit the galactoside-binding of Gal-9, and sucrose was added as a control. CCK-8 reagent (10 $\mu \mathrm{l})$ was added to each well, and the plates were incubated at $37^{\circ} \mathrm{C}$ for $3 \mathrm{~h}$. The absorbance of each well was measured at $450 \mathrm{~nm}$ using an auto-microplate reader.
Enzyme-linked immunosorbent (ELISA) assay. Cell apoptosis assays that measured the amounts of caspase-cleaved keratin-18 (CCK-18) were performed using the M30-ApoptoSensek ELISA kit (Peviva AB) (28). Each cell type $\left(5 \times 10^{3}\right.$ cells per well) was seeded into a 96-well plate and cultured in $100 \mu \mathrm{l}$ of culture medium for $24 \mathrm{~h}$. Seeded cells were then treated with $0.3 \mu \mathrm{M}$ of Gal-9. The rest of the experiments were carried out according to the manufacturer's instructions. The amount of antigen in the controls and samples was calculated by interpolation from a standard curve.

Flow cytometry analysis of the cell cycle and apoptosis. We conducted a flow cytometric analysis using the Cycle Phase Determination kit (Cayman Chemical Co.) to evaluate the mechanism of growth inhibition by Gal-9. CW-2 cells were digested with $0.25 \%$ trypsin and plated in 100-mm-diameter dishes at $1.0 \times 10^{6}$ cells per dish. After incubation for $24 \mathrm{~h}$ without FBS, CW-2 cells were treated with $0.3 \mu \mathrm{M}$ of Gal-9 or dimethyl sulfoxide (DMSO; control) for another $24 \mathrm{~h}$, then harvested, washed with phosphate-buffered saline (PBS), suspended in $500 \mu \mathrm{l}$ of PBS plus $10 \mu \mathrm{l}$ of RNase A $(250 \mu \mathrm{g} / \mathrm{ml})$ and $10 \mu \mathrm{l}$ of propidium iodide (PI) stain $(100 \mu \mathrm{g} / \mathrm{ml})$, and incubated for $30 \mathrm{~min}$.

To determine the apoptosis rate of CW-2, CACO-2, and WiDr cells, we used flow cytometry and the Annexin V-FITC Early Apoptosis Detection Kit (Cell Signaling Technology, Inc.). CW-2, CACO-2 and WiDr cells were plated in 100-mm-diameter dishes at $1.0 \times 10^{6}$ cells per dish and treated with $0.3 \mu \mathrm{M}$ Gal-9 or DMSO control for $24 \mathrm{~h}$. After incubation for $24 \mathrm{~h}, \mathrm{CW}-2, \mathrm{CACO}-2$ and WiDr cells were harvested, and washed with PBS. Staining was performed according to the manufacturer's protocol. After adding Annexin V-FITC and PI, we analyzed apoptosis and necrotic cell death. Flow cytometry was conducted with a Cytomics FC 500 flow cytometer (Beckman Coulter) equipped with a 480-nm argon laser. Cell percentages were analyzed with Kaluza software version 2.1 (Beckmann Coulter).

Cell lysate and tissue lysate. The lysates were prepared according to the methods described in our previous report (29). All steps were carried out at $4^{\circ} \mathrm{C}$. Protein concentrations were measured using a dye-binding protein assay based on the Bradford method (30).

Antibody arrays for phosphorylated receptor tyrosine kinases. Human phosphorylated receptor tyrosine kinases (p-RTKs) were assayed using Human phospho-RTK Array Kits (R\&D Systems), according to the manufacturer's instructions. Briefly, p-RTK array membranes were blocked with 5\% bovine serum albumin/0.01 M Tris- $\mathrm{HCl}, \mathrm{pH} 7.6$ (TBS) for $1 \mathrm{~h}$ and then incubated with $2 \mathrm{ml}$ of the lysate prepared from cell lines after normalization, so that the amounts of protein were equal. After three washes for 10 min each with TBS plus $0.1 \% \mathrm{v} / \mathrm{v}$ Tween-20 and two washes for $10 \mathrm{~min}$ with TBS alone to remove unbound material, the membranes were incubated with anti-phospho-tyrosine-horseradish peroxidase antibody for $2 \mathrm{~h}$ at room temperature. The unbound HRP antibody was washed out with TBS plus $0.1 \%$ Tween-20. Finally, each array membrane was exposed to an X-ray film using a chemiluminescence detection system (Perkin-Elmer Co.). 
Angiogenic profile analysis using an antibody array. The RayBio Human Angiogenesis Antibody Array (RayBiotech Inc.) was used according to the manufacturer's protocol. This method is a dot-based assay enabling detection and comparison of 20 angiogenesis-specific cytokines. Each array membrane was exposed to an X-ray film using a chemiluminescence detection system (PerkinElmer Co.).

Analysis of miRNA microarrays. The samples of cancer cell lines were processed for total RNA extraction with the miRNeasy Mini Kit (Qiagen $\mathrm{GmbH}$ ) according to the manufacturer's instructions. Typically, RNA samples showed $A_{260 / 280}$ ratios of between 1.9 and 2.1, using an Agilent 2100 Bioanalyzer (Agilent Technologies, Inc.).

After RNA measurement with an RNA 6000 Nano kit (Agilent Technologies, Inc.), the samples were labeled using a miRCURY Hy3/Hy5 Power labeling kit and were hybridized on a human miRNA Oligo chip10, version 19.0 (Toray Industries). Scanning was conducted with the 3D-Gene Scanner 3000 (Toray Industries). 3D-Gene extraction version 1.2 software (Toray) was used to read the raw intensity of the image. To determine the change in miRNA expression between Gal-9-treated and control samples, the raw data were analyzed via GeneSpring GX v 10.0 (Agilent Technologies, Inc.). Samples were first normalized relative to $28 \mathrm{~S}$ RNA, and the baseline was corrected to the median of all samples.

Replicate data were consolidated into two groups, those from Gal-9-treated cells and those from control cells, and were organized by using the hierarchical clustering and ANOVA functions in the GeneSpring GX v 10.0 software (Agilent Technologies, Inc.). Hierarchical clustering was performed by utilization of the clustering function (condition tree) and Euclidean correlation as a distance metric. Two-way ANOVA analysis and asymptotic P-value $(<0.05)$ computation without any error correction on the samples were performed to search for the miRNAs that varied most prominently across the different groups. Only changes $>50 \%$ for at least one of the time points for each sample were considered significant. All of the analyzed data were scaled by global normalization. The statistical significance of differentially expressed miRNAs was analyzed using Student's t-test.

All our micoroarray data in this study were submitted as a complete data set to the NCBI Gene Expression Omnibus (GEO), no. GSE163790 (https://www.ncbi.nlm.nih. gov/geo/query/acc.cgi?acc=GSE163790).

Xenograft model analysis. Animal experiments were performed according to the guidelines of the Committee on Experimental Animals of Kagawa University, Kagawa, Japan, following the National Institutes of Health guide for the care and use of laboratory animals. Approval Number of this animal experiment is HEISEI-25-164. We purchased 40 male athymic mice (BALB/c-nu/nu; 6 weeks old; 20-25 g) from Japan SLC (Shizuoka, Japan). The mice were maintained under specific pathogen-free conditions using a laminar airflow rack. The mice had continuous free access to sterilized ( $\gamma$-irradiated) food (CL-2; CLEA Japan, Inc.) and autoclaved water. A total of 40 mice were equally divided into two groups (CACO-2 group and $\mathrm{CW}-2$ group). Each mouse was subcutaneously inoculated with CACO-2 or CW-2 cells $\left(3 \times 10^{6}\right.$ cells per animal) in the flank region. Subsequently, when the xenografts were identifiable as masses with a maximal diameter $>3 \mathrm{~mm}$, we randomly assigned the animals to the following groups: i) CACO-2 only $(\mathrm{n}=5)$, ii) CACO-2 treated with $90 \mu \mathrm{g}$ of Gal-9 (n=5), iii) CW-2 only ( $\mathrm{n}=7)$, and iv) CW-2 treated with $90 \mu \mathrm{g}$ of Gal-9 $(\mathrm{n}=5)$. Our laboratory previously optimized the concentration of galectin- 9 for the treatment of various gastroenterological cancers in mouse animal model $(23,25,31)$. The Gal-9-treated groups were intraperitoneally (i.p.) injected with Gal-9 (90 $\mu \mathrm{g})$ five times per week; the control groups were administered 5\% DMSO alone. The tumor growth was monitored daily by the same investigators (AM and $\mathrm{KN}$ ), and the tumor size was measured two times per week. The tumor volume $\left(\mathrm{mm}^{3}\right)$ was calculated as the tumor length (mm) x tumor width $(\mathrm{mm})^{2} / 2$ (32). All animals were sacrificed on day 31 after the treatment, with all animals remaining alive until this time point. Tumor-bearing mice were euthanized using $\mathrm{CO}_{2}$ (20\% of the volume of the chamber per min) followed by cervical dislocation at the end of this experiment.

Gene transfection. The gene transfection miR-1237 inhibitor and negative control miRNA were obtained from Thermo Fisher Scientific, Inc. CW-2 and WiDr cells were seeded into 6-well plates. After $24 \mathrm{~h}$, the CW-2 and WiDr cells were transfected with the miR-1237 inhibitor or negative control miRNA at a final concentration of $0.3 \mu \mathrm{M}$ using Lipofectamine RNAiMAX (Invitrogen; Thermo Fisher Scientific, Inc.). After $48 \mathrm{~h}$ of incubation, the cells were harvested and washed with ice-cold PBS for subsequent analysis. The integrity of miR-1237 transfection was confirmed using real-time RT-PCR (Fig. S1). However, no miR-1237 reduction was detected in both cancer cell lines after microRNA inhibitor transfection. This inhibitor just binds to specific microRNA and stops translation of target gene and therefore, no reduction in specific miRNA was detected using real-time RT-PCR. In addition, no obvious miR-1237 target was published (no obvious downstream pathway). We demonstrated the differences in phenotype using MTT assay after miR-1237 inhibition.

Statistical analysis. All analyses were conducted using the GraphPad Prism 8.4.2 software (GraphPad Software, Inc.). Two-tailed paired or unpaired analysis between the groups was conducted using Student's t-test. For comparison of multiple groups, Kruskal-Wallis test was first performed, and then Dunnett test was conducted as a post hoc test. $\mathrm{P}<0.05$ was considered to indicate a significant difference between groups.

\section{Results}

Gal-9 suppresses the proliferation of human colon and colorectal cancer cells. To evaluate the effects of Gal-9 on the growth of human colon and colorectal cancer cells in vitro, we examined the effects of Gal-9 on the proliferation of the five colon cancer and colorectal cell lines CACO-2, CW-2, COLO-320, LoVo, and WiDr. Cells were grown in $10 \%$ FBS and treated with $0.01,0.03,0.10$, and $0.30 \mu \mathrm{M}$ of Gal-9 with untreated cells as controls. The cell proliferation assay was conducted $48 \mathrm{~h}$ after the addition of Gal-9. As shown in Fig. 1A and B, Gal-9 led to a dose-dependent and strong inhibition of cell proliferation in CACO-2 and CW-2, which are Gal-9-sensitive colon cancer cell lines. However, a significant 

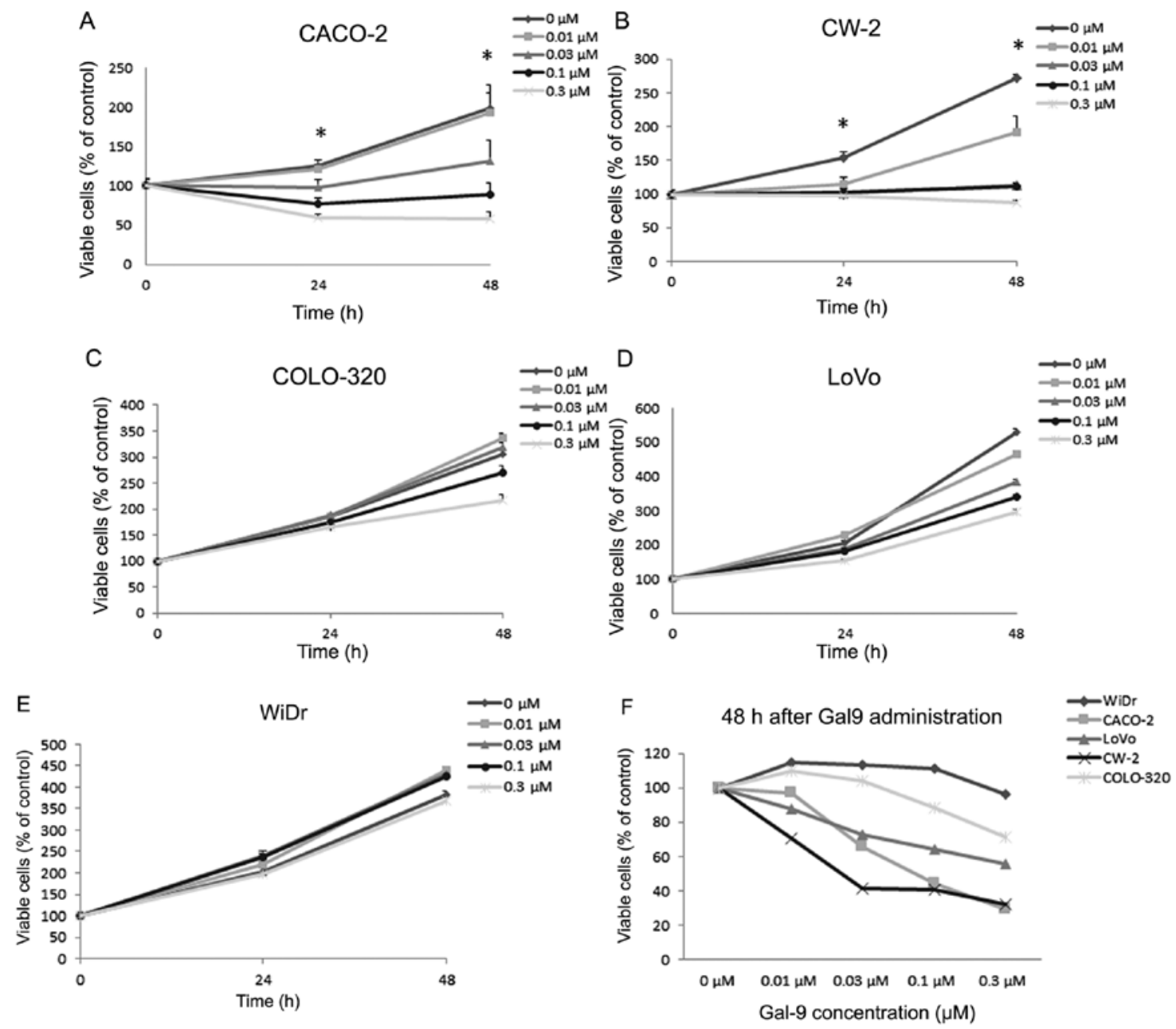

Figure 1. Gal-9 inhibits the proliferation of colon cancer cell lines. (A) CACO-2, (B) CW-2, (C) COLO-320, (D) LoVo, and (E) WiDr cells were treated with varying concentrations of Gal-9 $(0.01,0.03,0.1$, and $0.3 \mu \mathrm{M})$, and cell counts were performed daily from time 0 to $48 \mathrm{~h}$. The mean cell numbers from three independent cultures are shown. (F) The results are also expressed as percentages of viable cells compared to control $48 \mathrm{~h}$ after Gal-9 treatment. In CACO-2 and CW-2 cells, the conditions at 24 and $48 \mathrm{~h}$ in cells treated with Gal-9 were significantly different from those in the control ("P<0.05). Gal-9, galectin-9.

antiproliferative effect of Gal-9 on COLO-320, LoVo, and WiDr cell lines was not detected (Fig. 1C-E). These results are also expressed as percentages of viable cells compared to control $48 \mathrm{~h}$ after Gal-9 treatment (Fig. 1F).

Gal-9 induces apoptosis in Gal-9-sensitive CACO-2, CW-2 cells, but not in WiDr cell. CCK-18 is produced specifically in apoptosis. We performed ELISAs to determine the levels of CCK-18 in colorectal cancer cells treated with $0.3 \mu \mathrm{M}$ Gal-9. We found that Gal-9 significantly increased the CCK-18 levels in Gal-9-sensitive CACO-2 and CW-2 cells, but not in WiDr cells (Fig. 2). To further examine whether Gal-9 promotes apoptosis, we also assessed an apoptosis marker in CW-2, CACO-2, and WiDr cells treated for $24 \mathrm{~h}$ with $0.3 \mu \mathrm{M} \mathrm{Gal}-9$. In flow cytometry measurements, the percentages of Annexin $\mathrm{V}^{+}$cells were significantly increased in Gal-9-treated CW-2 and CACO-2 cells, but not in WiDr cells (Fig. 3). This suggests that Gal-9 administration induced apoptosis in Gal-9-sensitive cell lines.

Differences in phosphorylated receptor tyrosine kinases with and without Gal-9 treatment in Gal-9-sensitive and -resistant colon cancer and colorectal cell lines. We next used a p-RTK array system to identify 'key RTKs' associated with the antitumor effect of Gal-9. By using the antibody array (Fig. 4), we simultaneously screened the expression of 42 different activated RTKs in CACO-2, CW-2, and WiDr cell lines with and without the addition of $0.3 \mu \mathrm{M}$ Gal-9. It was noted that Gal-9 enhanced the expression of ALK, DDR1, and EphA10 in Gal-9-sensitive CW-2 cells (Fig. 4). By contrast, CACO-2 cells and Gal-9-resistant WiDr cells did not exhibit a change in the expression of the activated RTKs.

Effects of Gal-9 on angiogenesis in Gal-9-sensitive vs. -resistant colon and colorectal cancer cells. In order to examine the relationship between angiogenesis and Gal-9, an angiogenesis antibody array system was used to identify key angiogenesis-related molecules associated with the antitumor effect of Gal-9 (Fig. 5). By using the antibody array, we simultaneously screened the expression of 20 different angiogenesis-associated molecules in CACO-2, CW-2, and WiDr cells with or without Gal-9 administration. The expression levels of interleukin-8 (IL-8) and tissue inhibitor of metalloproteinases-2 (TIMP-2) were induced by Gal-9 treatment in Gal-9-resistant WiDr cells as detected by the protein array (Fig. 5). In Gal-9-sensitive CACO-2 and CW-2 cells, the expression of angiogenesis molecules did not change following treatment with Gal-9 (Fig. 5). 

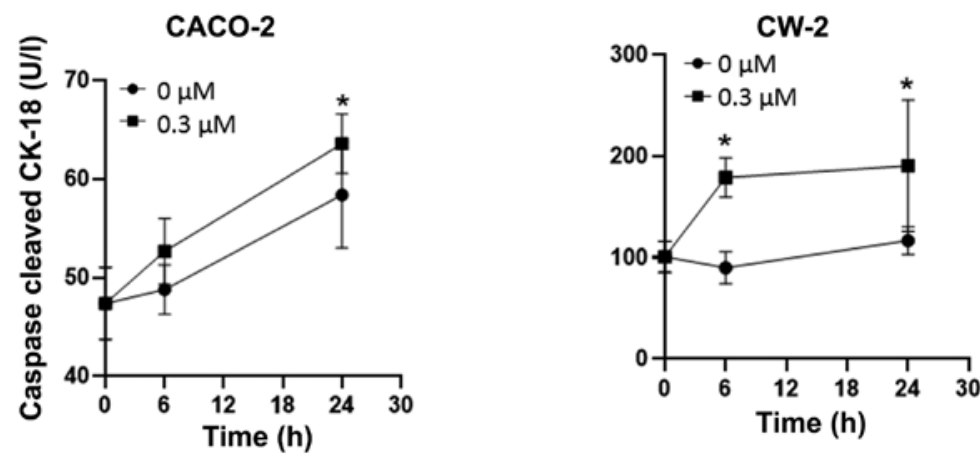

WiDr

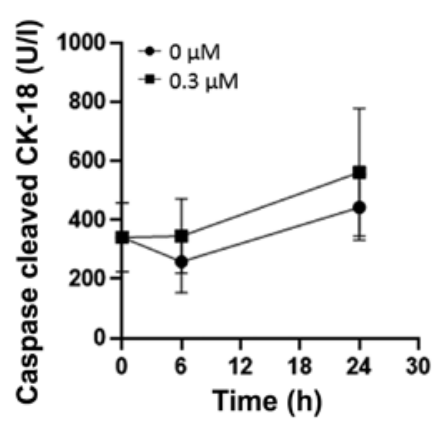

Figure 2. Gal-9 induces apoptosis in CACO-2, CW-2, and WiDr cells. Caspase-cleaved keratin 18 (CK-18), which is specifically produced in apoptosis, was identified using enzyme-linked immunosorbent assays. Following Gal-9 treatment, the expression of caspase-cleaved CK-18 was significantly upregulated in CACO-2 and CW-2 cells, but not in WiDr cells ( $\left.{ }^{*} \mathrm{P}<0.05, \mathrm{n}=3\right)$. Gal-9, galectin-9.

Gal-9-induced cell cycle arrest in the $G_{0} / G_{1}$ phase. To examine whether growth inhibition was due to cell cycle changes, we investigated the cell cycle profiles of CW-2 cells $24 \mathrm{~h}$ after treatment, with or without $0.3 \mu \mathrm{M}$ Gal-9, using flow cytometry. Treatment with $0.3 \mu \mathrm{M}$ Gal-9 significantly increased the percentage of cells in the $\mathrm{G}_{0} / \mathrm{G}_{1}$ phase and significantly decreased the percentage of cells in the $S$ phase at $24 \mathrm{~h}$ after treatment (Fig. 6). This result indicates that Gal-9 blocked the cell cycle progression from the $\mathrm{G}_{0} / \mathrm{G}_{1}$ phase to the $S$ phase and may induce apoptosis.

Differences in cell cycle-related protein expression in $\mathrm{CACO}-2$ and $C W$-2 cells with and without Gal-9 treatment. To investigate the effects of Gal-9 administration on Gal-9-sensitive cells, we examined the cell cycle-related protein expression in CACO-2 and $\mathrm{CW}-2$ cells using western blotting. Cells were treated with 0 or $0.3 \mu \mathrm{M}$ Gal-9 for $24-48 \mathrm{~h}$. We observed no obvious reduction in cyclin D1, which is one of the key proteins involved in the transition from the $G_{0}$ to the $G_{1}$ phase, due to Gal-9 treatment in CACO-2 and CW-2 cells (Fig. 7). Additionally, the analysis of other proteins associated with $\mathrm{G}_{0} / \mathrm{G}_{1}$ transition indicated that Cdk4 and Cdk6, the catalytic subunits of cyclin D1, were not decreased at any time point in CACO-2 cells after Gal-9 treatment (Fig. 7). Cyclin E, which is the key cyclin for $G_{1} / S$ transition, was unchanged, and no $\mathrm{pRB}$ reduction was detected in CACO-2 and CW-2 cells after Gal-9 treatment (Fig. 7).

These findings suggest that Gal-9 is not involved in the regulation of cell cycle-related molecules in Gal-9-sensitive cells.

Gal-9 inhibits tumor proliferation in vivo. To determine whether Gal-9 can affect tumor growth in vivo, we subcutaneously inoculated nude mice with CACO-2 and CW-2 cells, followed by i.p. injection of Gal-9. The Gal-9 treatment at a dose of $90 \mu \mathrm{g}$ significantly inhibited tumor growth in both CACO-2 and CW-2 implanted tumors compared to untreated control mice, as determined by integrated tumor growth curves (Student's t-test, "P<0.05; Fig. 8). Gal-9 had no apparent toxic effects on the mice including their body weight during the study (data not shown). Furthermore, all animals survived until the end of the experiment.

miRNA profiles of the cell lines with and without Gal-9 treatment. Using a custom microarray platform, we analyzed the expression levels of 2,555 human miRNA probes in colon cancer cell lines in vitro and in vivo with and without Gal-9 treatment. As shown in Fig. 9, when the expression of miRNAs was studied in CACO-2 cells with and without Gal-9 treatment in vitro and in vivo, only hsa-miR-1246 was found to be commonly upregulated $24 \mathrm{~h}$ after Gal-9 treatment $(\mathrm{P}=0.00000689$ and $\mathrm{P}=0.000804$, respectively), whereas hsa-miR-15b-5p and hsa-miR-1237 expression levels were significantly changed in $\mathrm{CW}-2$ cells in vitro $(\mathrm{P}=0.00956$ and $\mathrm{P}=0.0033$, respectively) and in vivo $(\mathrm{P}=0.00582$ and $\mathrm{P}=0.000289$, respectively). In addition, only hsa-miR-1237 was commonly altered in CACO-2 cells in vitro, CW-2 cells in vitro, and $\mathrm{CW}-2$ cells in vivo.

Unsupervised hierarchical clustering analysis with Pearson's correlation showed that CACO-2 cells in vitro, CW-2 cells in vitro, and CW-2 cells in vivo treated with Gal-9 clustered together and separately from untreated CACO-2 and CW-2 cells (Fig. 9).

Inhibition of miR-1237 reduces cell proliferation in colon cancer cells. Our in vitro findings led us to hypothesize that Gal-9 might inhibit the proliferation of colon and colorectal cancer cells via miR-1237 downregulation. To examine 

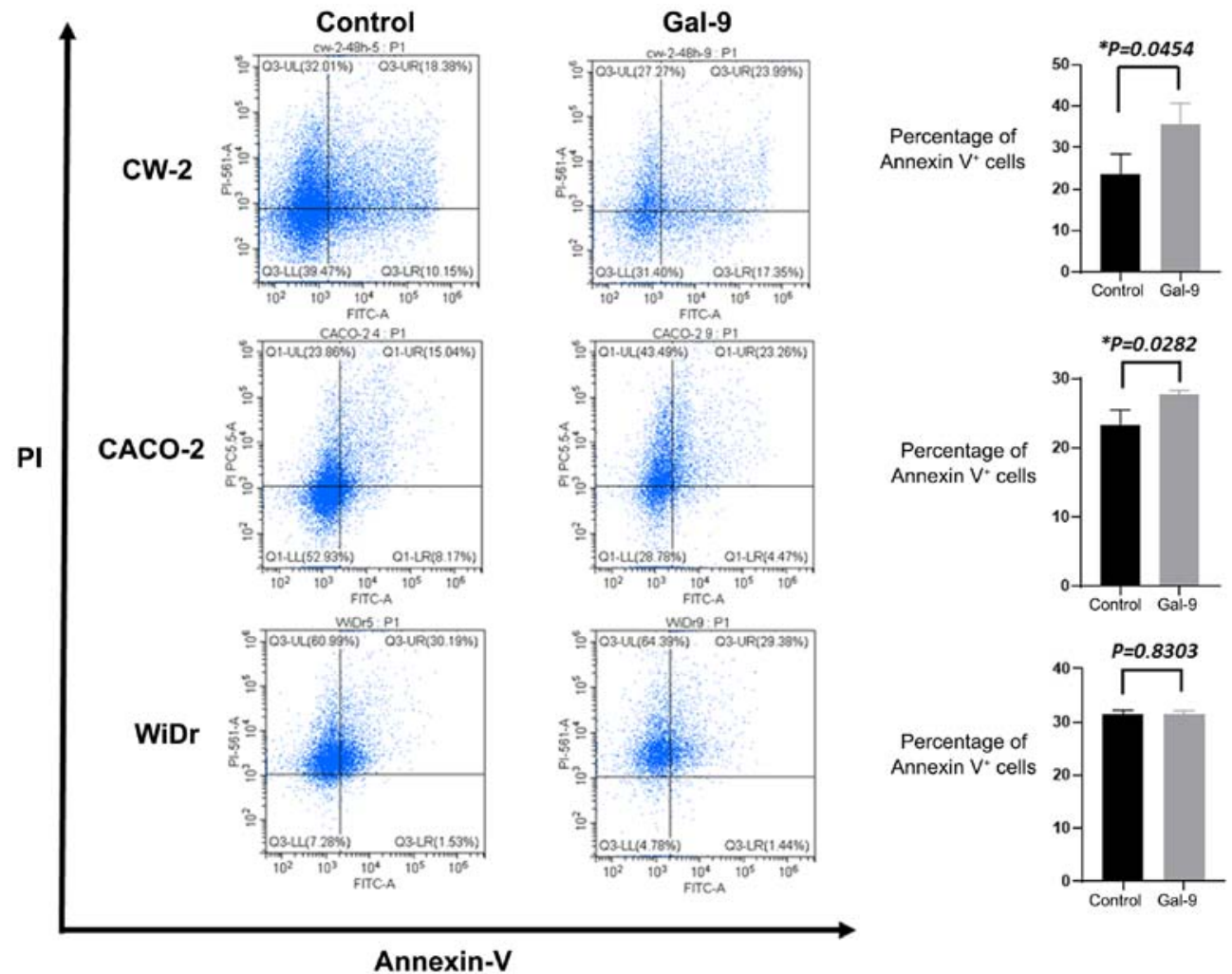

Figure 3. Gal-9 promotes apoptosis in CW-2, CACO-2, and WiDr cells. Flow cytometry assessment of apoptosis in CW-2 cells treated with $0.3 \mu \mathrm{M}$ Gal-9 for $24 \mathrm{~h}$. Percentages of Annexin $\mathrm{V}^{+}$cells were significantly increased in Gal-9-treated cells indicating that Gal-9 induces apoptosis in CW-2 and CACO-2 cells, but not in WiDr cells ( $\left.{ }^{*} \mathrm{P}<0.05\right)$. PI, propidium iodide; Gal-9, galectin-9.

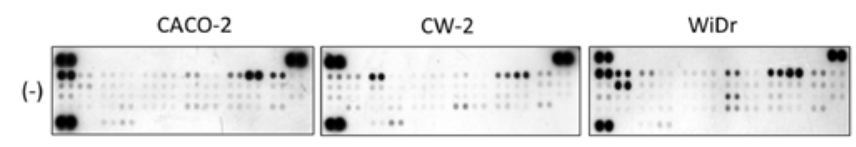

Gal-9

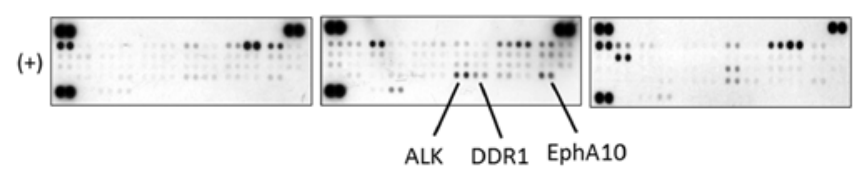

Figure 4. Effects of Gal-9 administration on phosphorylated tyrosine kinase receptors in CACO-2, CW-2, and WiDr cells. Representative expression of various phosphorylated tyrosine kinase receptors in CACO-2, $\mathrm{CW}-2$, and WiDr cells treated with (+) or without (-) Gal-9. Enhanced expression of ALK, DDR1, and EphA10 was detected in CW-2 cells treated with Gal-9. Gal-9, galectin-9.

this hypothesis, we examined CW-2 and WiDr cells transfected with miR-1237 inhibitor or negative control miRNA. After $24 \mathrm{~h}$ of incubation, we examined the cell proliferation with or without miR-1237. Interestingly, the percentages of viable cells were significantly diminished $24 \mathrm{~h}$ after miR-1237 inhibitor transfection in the colon cancer CW-2 cells, but not in the colorectal cancer WiDr cells (Fig. 10). This revealed that miR-1237 inhibited by Gal-9 suppressed the cell proliferation in one of the Gal-9-sensitive colon cancer cell lines.

\section{Discussion}

Colorectal cancer (CRC) is a commonly disease worldwide, being the third and second commonly diagnosed cancer in

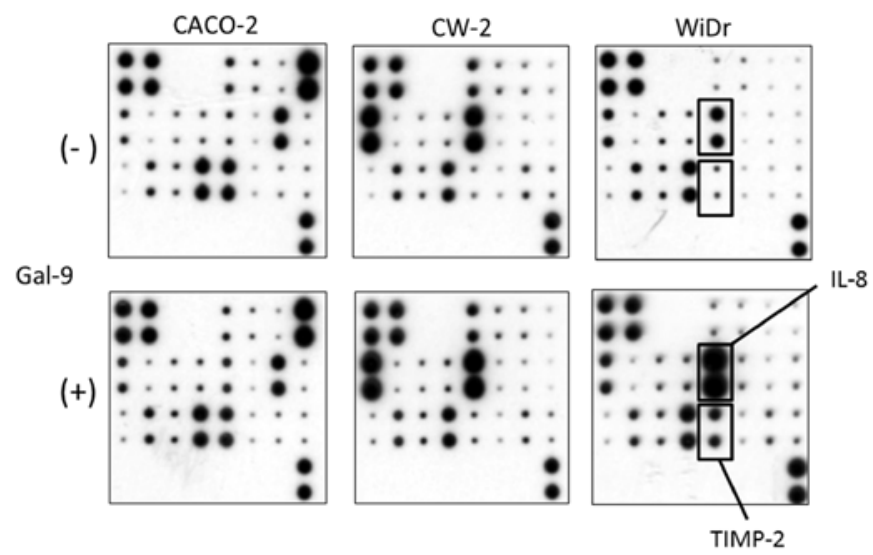

Figure 5. Effects of Gal-9 on angiogenesis proteins in CACO-2, CW-2, and WiDr cells. Representative expression of various angiogenesis-related proteins in CACO-2, CW-2, and WiDr cells with (+) or without (-) Gal-9 treatment. Increased expression levels of interleukin (IL)-8 and tissue inhibitor of metalloproteinases (TIMP)-2 were detected in WiDr cells treated with Gal-9. Gal-9, galectin-9.

men and women, respectively (33). Although the overall incidence and mortality have dramatically declined over the last few decades, it remains a major health issue (3-6). Currently, CRC treatment is mainly based on surgical removal of tumor tissue, chemotherapy, and radiotherapy, with the recent addition of immunotherapy (34). However, the overall survival rate of advanced CRC patients remains poor (35). Thus, there is a strong demand for new therapeutic approaches to CRC therapy. 
Control

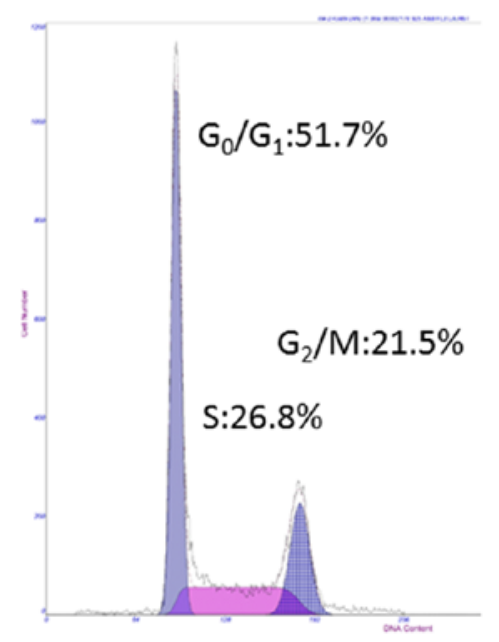

Galectin-9

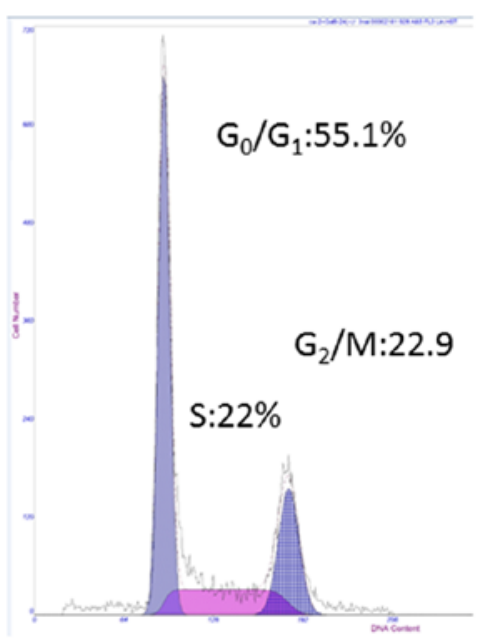

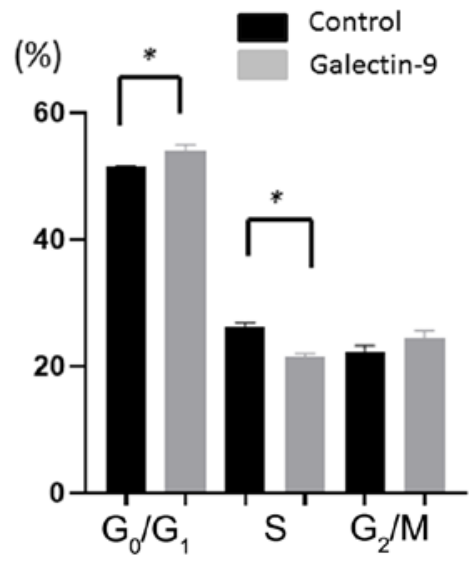

Figure 6. Flow cytometric analysis of CW-2 cells treated with $0.3 \mu \mathrm{M}$ Gal-9 for $24 \mathrm{~h}$. Gal-9 increased the population of cells in the $\mathrm{G}_{0} / \mathrm{G}_{1}$ phase and decreased the population of cells in the $S$ phase. Gal-9 blocked the cell cycle progression from the $G_{0} / G_{1}$ phase to the $S$ phase (* $\left.P<0.05\right)$. Gal-9, galectin-9.

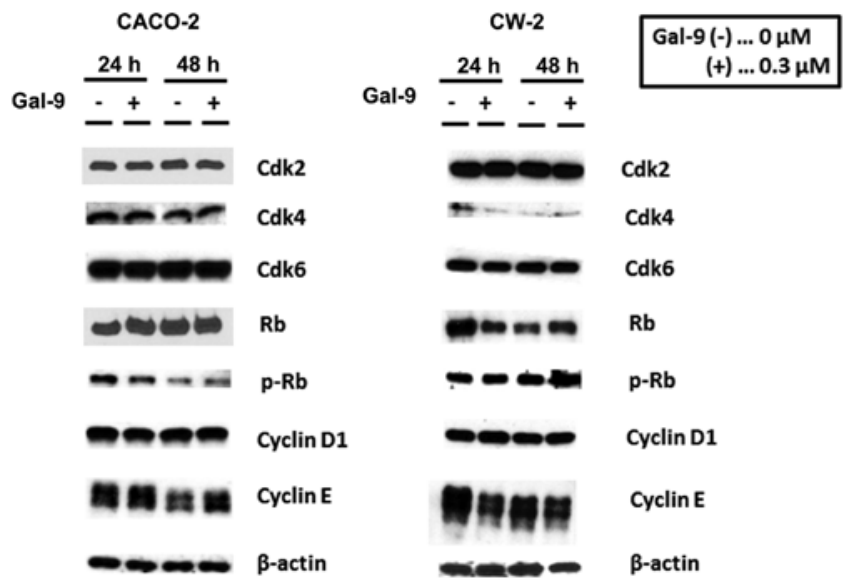

Figure 7. Effects of Gal-9 on cell cycle regulatory molecules in CACO-2 and CW-2 cells. Western blotting for Cdk2, Cdk4, Cdk6, Rb, p-Rb, cyclin D1, and cyclin E in CACO-2 and CW-2 cells after 24 or $48 \mathrm{~h}$ of $0.3 \mu \mathrm{M}$ Gal-9 treatment. At both 24 and $48 \mathrm{~h}$, cyclin D1 was not decreased in Gal-9-treated cells compared to untreated cells. In CACO-2 cells, the quantities of cyclin D1, Cdk4, and Cdk6 did not differ between treated and untreated cells at any time point. The $\mathrm{p}-\mathrm{Rb}$ expression levels were not decreased in the CACO-2 and CW-2 cells following Gal-9 treatment. $\beta$-actin was used as the loading control. Gal-9, galectin-9.

Nobumoto et al reported that Gal-9 suppresses tumor metastasis by inhibiting adhesion between endothelium and extracellular matrix (36). Additionally, reduced expression of Gal-9 is related to poor outcome in colon cancer (37). However, the antitumor effect of recombinant Gal-9 on colon cancer and colorectal cells in vitro is unknown. In the present study, we found that Gal-9 inhibited the proliferation of colon cancer cell lines and we the miRNA associated with the antitumor effect of Gal-9 in colon cancer.

Recombinant Gal-9 was found to inhibit proliferation in various types of cancers such as hepatocellular carcinoma by inducing apoptosis (23). Our study results revealed that Gal-9 suppresses cell proliferation in human colon and colorectal cancer cell lines in vitro. Gal-9 led to a dose-dependent and strong inhibition of cell proliferation in CACO-2 and CW-2 cell lines, but not in COLO-320, LoVo, and WiDr cell lines.
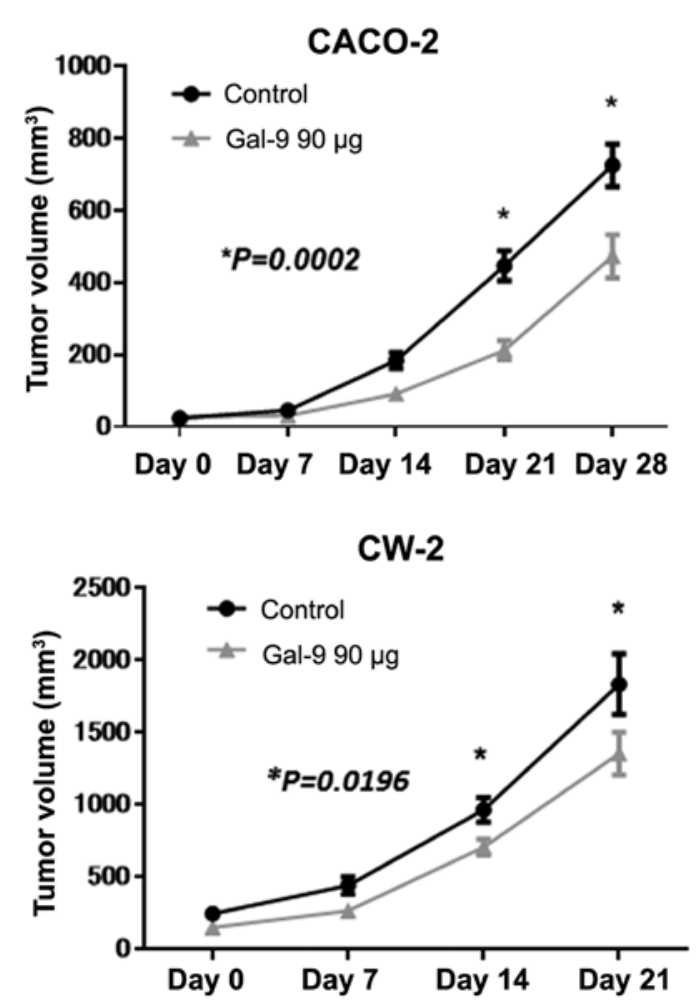

Figure 8. In vivo antitumor effects of Gal-9 on established colon cancer in nude mice. CACO-2 and CW-2 cells were implanted subcutaneously into the flank regions of nude mice. When a tumor became palpable, $90 \mu \mathrm{g}$ Gal-9 was injected subcutaneously four times per week. Animals in the control group developed rapidly growing subcutaneous colon cancer. By contrast, animals in the Gal-9-treated groups exhibited significantly retarded tumor development. The tumors in the mice treated with Gal-9 were significantly smaller than those in mice without Gal-9 treatment $\left({ }^{*} \mathrm{P}<0.05\right)$. Gal-9, galectin-9.

Ahmed et al demonstrated that TP53 is mutated in the CACO-2 cell line and BRAF, PIK3CA, and TP53 are mutated in the WiDr cell line (38). In addition, LoVo cells have a KRAS mutation (38). These results indicate that colon and colorectal cancer cell lines with more mutations of genes critical for cancer may be resistant to Gal-9. 

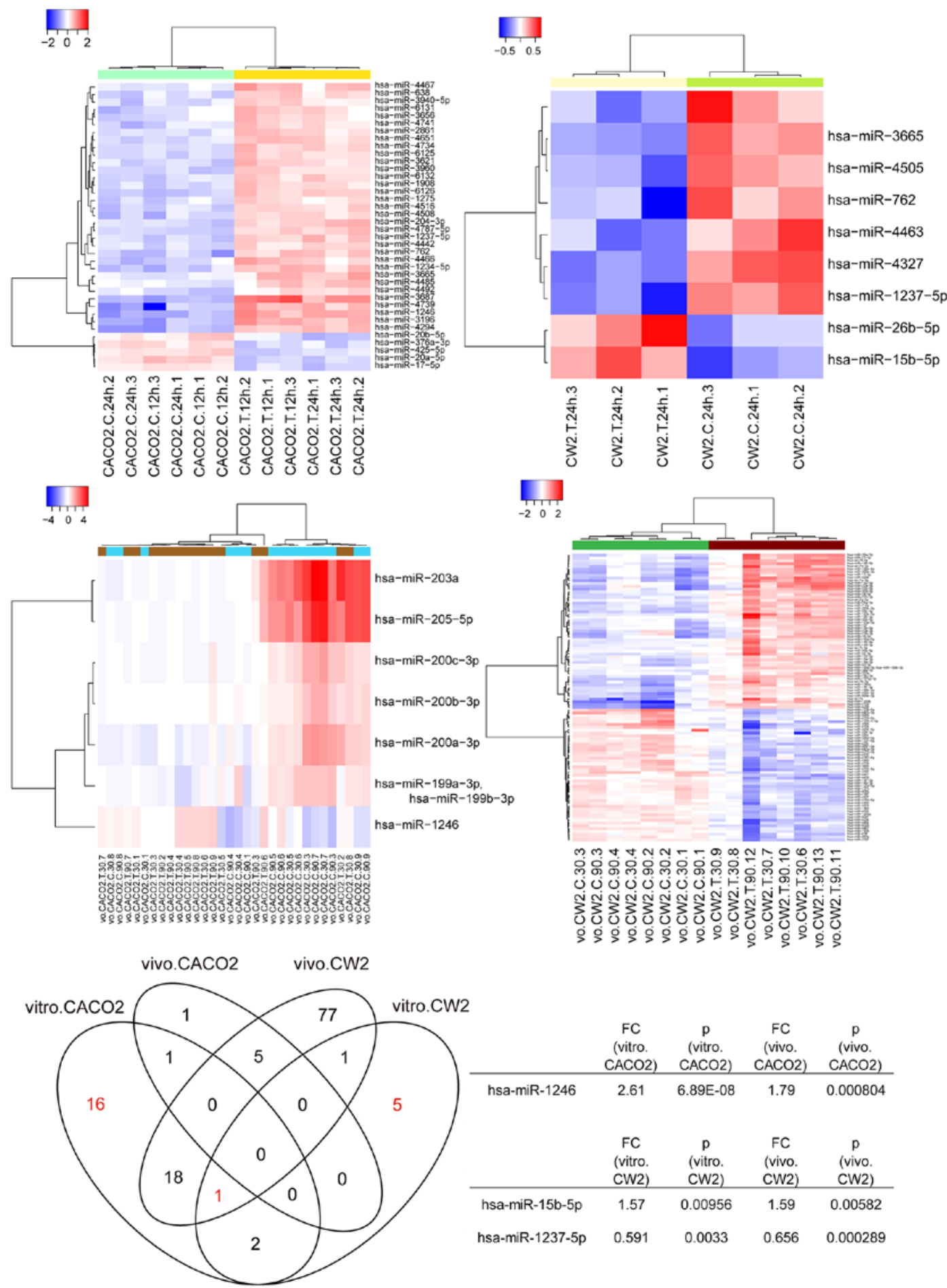

Figure 9. Hierarchical clustering of CACO-2, CW-2, and WiDr cells with and without Gal-9 treatment. CACO-2 cells were clustered according to the expression profiles that were differentially expressed between treated and untreated CACO-2 cells in vitro. CW-2 cells were clustered separately according to treated and untreated CW-2 cells in vitro and in vivo. The analyzed samples are in columns, and the miRNAs are presented in rows. The miRNA clustering tree is shown on the left, and the sample-clustering tree appears at the top. The color scale shown at the top illustrates the relative expression level of miRNAs; red represents a high expression level, and blue represents a low expression level. Only hsa-miR-1246 was detected to be commonly upregulated $24 \mathrm{~h}$ after Gal-9 treatment in CACO-2 cells $(\mathrm{P}=0.00000689$ and $\mathrm{P}=0.000804)$, whereas hsa-miR-15b-5p and hsa-miR-1237 expression levels were significantly changed in $\mathrm{CW}-2$ cells in vitro $(\mathrm{P}=0.00956$ and $\mathrm{P}=0.0033)$ and in vivo $(\mathrm{P}=0.00582$ and $\mathrm{P}=0.000289)$. In addition, only hsa-miR-1237 was commonly altered in $\mathrm{CACO}-2$ cells in vitro, CW-2 cells in vitro, and CW-2 cells in vivo. Gal-9, galectin-9.

Caspase cleavage of cytokeratin (CCK-18) upregulation occurs as an early event during apoptosis following activation of apoptosis executioners, particularly effector caspases, yet its levels remain unchanged during other types of cell death such as autophagy or necrosis (39). In our study, Gal-9 increased the levels of CCK-18 in CACO-2 and CW-2 cell lines which are sensitive to Gal-9, but not in the WiDr cell line which is resistant to Gal-9. Moreover, flow cytometry experiments revealed that the percentages of Annexin $\mathrm{V}^{+} \mathrm{CW}-2$ cells were significantly increased after Gal-9 treatment, indicating that 


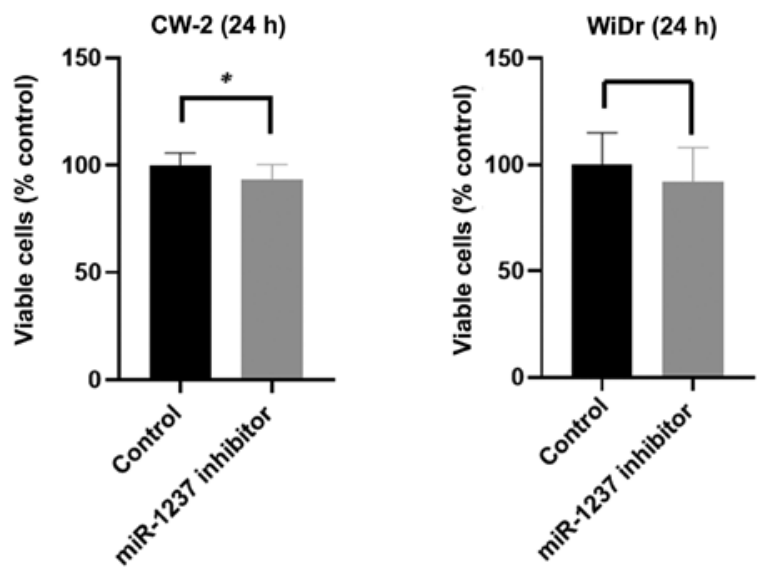

Figure 10. Inhibition of miR-1237 reduces cell proliferation in colon cancer cells. Targetable microRNA miR-1237 downregulated by Gal-9 inhibited the proliferation of CW-2 cells, but not of WiDr cells, treated with $0.3 \mu \mathrm{M}$ Gal-9 for $24 \mathrm{~h}\left({ }^{*} \mathrm{P}<0.05\right)$. Gal-9, galectin-9.

the presence of Gal-9 caused apoptosis in these cells. These data suggest that Gal-9 suppresses the cell proliferation of Gal-9-sensitive colon and colorectal cancer cells by inducing apoptosis.

Since the discovery of receptor tyrosine kinases (RTKs), their functions have been examined over the years as key regulators of proliferation, differentiation, and metastasis in gastric cancer (40) and colon cancer (41). Using p-RTK arrays, our study showed increased activation of ALK, DDR1, and EphA10 following Gal-9 treatment in Gal-9-sensitive cells (CW-2) but not in Gal-9-resistant cells (WiDr). These RTKs are expressed in various cancers and are involved in cell proliferation and the prevention of apoptosis (42-44). In Gal-9-sensitive cells, these p-RTKs were not activated in CACO-2 cells. Gal-9 might have other pathways to inhibit cell proliferation and induce apoptosis. These results suggest that the activation of these identified RTKs induced by Gal-9 may be associated with the predisposition of a type of Gal-9-sensitive cell lines to induce cell growth inhibition and apoptosis.

Galectins are important regulators of tumor progression that influence tumor cell transformation, tumor immune escape, and tumor angiogenesis (12-14). Using an angiogenesis-related protein assay, we discovered that IL- 8 and TIMP-2 were stimulated in WiDr cells which is a Gal-9-resistant cell line. Specifically, high levels of IL- 8 may be associated with poor prognosis, as judged by stage and histology, and may be indicative of a more aggressive cancer type (45-47). These data suggest that the Gal-9-resistant colorectal cancer cells escaping from the antitumor effect of Gal-9 may produce angiogenesis-related proteins. Nevertheless, the effect of Gal-9 on angiogenesis in colon cancer remains controversial.

miRNAs, small noncoding RNA sequences, have been shown to regulate the development and progression of various cancers (48). Using miRNA expression arrays to identify the miRNAs associated with the antitumor effect of Gal-9, we determined the variations in the miRNA profiles in CACO-2 and CW-2 cell lines in vitro and in vivo with or without Gal-9 treatment. The cluster analysis clearly demonstrated that Gal-9 treatment affected the expression of numerous miRNAs. In the analysis, we selected sets of miRNAs that displayed a significant alteration in their expression levels following Gal-9 treatment. These altered miRNAs may provide clues to the molecular basis of the anticancer effects of Gal-9 in colon cancer. Our data showed that miR-1246 was upregulated in CACO-2 cells in vitro and in vivo and that miR-1237-5p was downregulated in CW-2 cells in vitro and in vivo after treatment with Gal-9. To determine whether the loss of miR-1237 can inhibit cell proliferation, we further assayed the effect of miR-1237 inhibition on the cell proliferation of CW-2 and WiDr cells. Remarkably, miR-1237 inhibition suppressed cell proliferation in CW-2, but not in WiDr cells. Thus, Gal-9 inhibited cell proliferation through miR-1237 in Gal-9-sensitive CW-2 cells. In addition, miR-15b-5p was also previously found to be significantly upregulated in CW-2 cells in vitro and in vivo by Gal-9 treatment. miR-1246 targets CADM1 in hepatocellular carcinoma (49), CXCR4 in lung cancer cells (50), and thrombospondin-2 in cervical cancer cells (51) leading to apoptosis and cell cycle arrest. On the other hand, miR-1246 has been reported to be a target of the p53 family, and inhibits Down syndrome-associated DYRK1A, consequently activating NFTA1c and inducing apoptosis (46). In addition, miR-15b-5p targets SIRT1 in colorectal cancer (52) and Axin2 in liver cancer (53). Our previous studies revealed that Gal-9 treatment leads to the upregulation of miR-1246 in hepatocellular carcinoma (23) and cholangiocarcinoma (25), suggesting that miR-1246 may be associated with the antitumor effect of Gal-9 in various cancer cells. In addition, Tang et al demonstrated that miR-1237 was associated with EMT and cancer metastasis in nasopharyngeal carcinoma (54). These reports suggest that several microRNAs might be key molecules for Gal-9-induced inhibition of tumor growth.

In conclusion, our results revealed that Gal-9 suppresses human colon cancer cell proliferation, possibly by inducing apoptosis through the alteration of miRNAs. These findings suggest that Gal-9 may be a candidate for a new therapeutic approach to the treatment of colon cancer.

\section{Acknowledgements}

We thank Ms. Kayo Hirose for providing technical assistance.

\section{Funding}

This study received no funding from external sources.

\section{Availability of data and materials}

All data generated or analyzed during this study are included in this published article.

\section{Authors' contributions}

AM designed the concept of the present study. AM, MH and TM designed this study. AM, KN, JT, KF, KT, MN, TT, KO, $\mathrm{TC}$ and SF performed the in vitro experiments. AM and $\mathrm{KN}$ performed the in vivo experiments. AM, HI, TN, AN and TH analyzed the microRNA profiles. AM wrote the draft of the 
manuscript, and TN, MH, AN, TH and TM reviewed it. All authors read and approved the final manuscript.

\section{Ethics approval and consent to participate}

Animal experiments were approved by the Committee on Experimental Animals of Kagawa University (approval no. HEISEI25-164).

\section{Patient consent for publication}

Not applicable.

\section{Competing interests}

The authors declare that they have no competing interests.

\section{References}

1. Bray F, Ferlay J, Soerjomataram I, Siegel RL, Torre LA and Jemal A: Global cancer statistics 2018: GLOBOCAN estimates of incidence and mortality worldwide for 36 cancers in 185 countries. CA Cancer J Clin 68: 394-424, 2018.

2. Benson AB, Venook AP, Al-Hawary MM, Cederquist L, Chen YJ, Ciombor KK, Cohen S, Cooper HS, Deming D, Engstrom PF, et al: NCCN Guidelines insights: Colon cancer, version 2.2018. J Natl Compr Canc Netw 16: 359-369, 2018.

3. Boland GM, Chang GJ, Haynes AB, Chiang YJ, Chagpar R, Xing Y, Hu CY, Feig BW, You YN and Cormier JN: Association between adherence to National Comprehensive Cancer Network treatment guidelines and improved survival in patients with colon cancer. Cancer 119: 1593-1601, 2013.

4. Booth CM, Nanji S, Wei X, Peng Y, Biagi JJ, Hanna TP, Krzyzanowska MK and Mackillop WJ: Use and effectiveness of adjuvant chemotherapy for stage III colon cancer: A population-based study. J Natl Compr Canc Netw 14: 47-56, 2016.

5. Casadaban L, Rauscher G, Aklilu M, Villenes D, Freels S and Maker AV: Adjuvant chemotherapy is associated with improved survival in patients with stage II colon cancer. Cancer 122 $3277-3287,2016$

6. Hines RB, Barrett A, Twumasi-Ankrah P, Broccoli D, Engelman KK, Baranda J, Ablah EA, Jacobson L, Redmond M, Tu W and Collins TC: Predictors of guideline treatment nonadherence and the impact on survival in patients with colorectal cancer. J Natl Compr Canc Netw 13: 51-60, 2015.

7. Sargent DJ, Marsoni S, Monges G, Thibodeau SN, Labianca R, Hamilton SR, French AJ, Kabat B, Foster NR, Torri V, et al: Defective mismatch repair as a predictive marker for lack of efficacy of fluorouracil-based adjuvant therapy in colon cancer J Clin Oncol 28: 3219-3226, 2010.

8. Kim JE, Hong YS, Kim HJ, Kim KP, Lee JL, Park SJ, Lim SB, Park IJ, Kim CW, Yoon YS, et al: Defective mismatch repair status was not associated with DFS and OS in stage II colon cancer treated with adjuvant chemotherapy. Ann Surg Oncol 22 (Suppl 3): S630-S637, 2015

9. McCleary NJ, Meyerhardt JA, Green E, Yothers G, de Gramont A Van Cutsem E, O'Connell M, Twelves CJ, Saltz LB, Haller DG and Sargent DJ: Impact of age on the efficacy of newer adjuvant therapies in patients with stage II/III colon cancer: Findings from the ACCENT database. J Clin Oncol 31: 2600-2606, 2013.

10. Yothers G, O'Connell MJ, Allegra CJ, Kuebler JP, Colangelo LH, Petrelli NJ and Wolmark N: Oxaliplatin as adjuvant therapy for colon cancer: Updated results of NSABP C-07 trial, including survival and subset analyses. J Clin Oncol 29: 3768-3774, 2011.

11. Tournigand C, André T, Bonnetain F, Chibaudel B, Lledo G, Hickish T, Tabernero J, Boni C, Bachet JB, Teixeira L and de Gramont A: Adjuvant therapy with fluorouracil and oxaliplatin in stage II and elderly patients (between ages 70 and 75 years) with colon cancer: Subgroup analyses of the multicenter international study of oxaliplatin, fluorouracil, and leucovorin in the adjuvant treatment of colon cancer trial. J Clin Oncol 30: 3353-3360, 2012

12. Thijssen VL, Heusschen R, Caers J and Griffioen AW: Galectin expression in cancer diagnosis and prognosis: A systematic review. Biochim Biophys Acta 1855: 235-247, 2015.
13. Wiersma VR, de Bruyn M, Helfrich W and Bremer E: Therapeutic potential of Galectin-9 in human disease. Med Res Rev 33 (Suppl 1): E102-E126, 2013.

14. Fujihara S, Mori H, Kobara H, Rafiq K, Niki T, Hirashima M and Masaki T: Galectin-9 in cancer therapy. Recent Pat Endocr Metab Immune Drug Discov 7: 130-137, 2013.

15. Hirashima M: Ecalectin/galectin-9, a novel eosinophil chemoattractant: Its function and production. Int Arch Allergy Immunol 122 (Suppl 1): S6-S9, 2000.

16. Matsumoto R, Matsumoto H, Seki M, Hata M, Asano Y, Kanegasaki S, Stevens RL and Hirashima M: Human ecalectin, a variant of human galectin-9, is a novel eosinophil chemoattractant produced by T lymphocytes. J Biol Chem 273: 16976-16984, 1998.

17. Matsushita N, Nishi N, Seki M, Matsumoto R, Kuwabara I, Liu FT, Hata Y, Nakamura T and Hirashima M: Requirement of divalent galactoside-binding activity of ecalectin/galectin-9 for eosinophil chemoattraction. J Biol Chem 275: 8355-8360, 2000.

18. Saita N, Goto E, Yamamoto T, Cho I, Tsumori K, Kohrogi H, Maruo K, Ono T, Takeya M, Kashio Y, et al: Association of galectin-9 with eosinophil apoptosis. Int Arch Allergy Immunol 128: 42-50, 2002.

19. Asakura H, Kashio Y, Nakamura K, Seki M, Dai S, Shirato Y, Abedin MJ, Yoshida N, Nishi N, Imaizumi T, et al: Selective eosinophil adhesion to fibroblast via IFN-gamma-induced galectin-9. J Immunol 169: 5912-5918, 2002.

20. Irie A, Yamauchi A, Kontani K, Kihara M, Liu D, Shirato Y, Seki M, Nishi N, Nakamura T, Yokomise H and Hirashima M: Galectin-9 as a prognostic factor with antimetastatic potential in breast cancer. Clin Cancer Res 11: 2962-2968, 2005.

21. Yamauchi A, Kontani K, Kihara M, Nishi N, Yokomise H and Hirashima M: Galectin-9, a novel prognostic factor with antimetastatic potential in breast cancer. Breast J 12 (Suppl 2): S196-200, 2006

22. Yasinska IM, Sakhnevych SS, Pavlova L, Teo Hansen Selnø A, Teuscher Abeleira AM, Benlaouer O, Gonçalves Silva I, Mosimann M, Varani L, Bardelli M, et al: The Tim-3-Galectin-9 pathway and its regulatory mechanisms in human breast cancer. Front Immunol 10: 1594, 2019.

23. Fujita K, Iwama H, Sakamoto T, Okura R, Kobayashi K, Takano J, Katsura A, Tatsuta M, Maeda E, Mimura S, et al: Galectin-9 suppresses the growth of hepatocellular carcinoma via apoptosis in vitro and in vivo. Int J Oncol 46: 2419-2430, 2015.

24. Kong F, Jin M, Cao D, Jia Z, Liu Y and Jiang J: Galectin-3 not Galectin-9 as a candidate prognosis marker for hepatocellular carcinoma. PeerJ 8: e9949, 2020.

25. Kobayashi K, Morishita A, Iwama H, Fujita K, Okura R, Fujihara S, Yamashita T, Fujimori T, Kato K, Kamada H, et al: Galectin-9 suppresses cholangiocarcinoma cell proliferation by inducing apoptosis but not cell cycle arrest. Oncol Rep 34: $1761-1770,2015$.

26. Muthusami S, Ramachandran I, Krishnamoorthy S, Sambandam Y, Ramalingam S, Queimado L, Chaudhuri G and Ramachandran IK: Regulation of microRNAs in inflammation-associated colorectal cancer: A mechanistic approach. Endocr Metab Immune Disord Drug Targets 21: 67-76, 2021.

27. Nishi N, Itoh A, Fujiyama A, Yoshida N, Araya S, Hirashima M, Shoji $\mathrm{H}$ and Nakamura T: Development of highly stable galectins: Truncation of the linker peptide confers protease-resistance on tandem-repeat type galectins. FEBS Lett 579: 2058-2064, 2005.

28. Schutte B, Henfling M, Kölgen W, Bouman M, Meex S, Leers MP Nap M, Björklund V, Björklund P, Björklund B, et al: Keratin $8 / 18$ breakdown and reorganization during apoptosis. Exp Cell Res 297: 11-26, 2004.

29. Masaki T, Tokuda M, Yoshida S, Nakai S, Morishita A, Uchida N, Funaki T, Kita Y, Funakoshi F, Nonomura T, et al: Comparison study of the expressions of myristoylated alanine-rich C kinase substrate in hepatocellular carcinoma, liver cirrhosis, chronic hepatitis, and normal liver. Int J Oncol 26: 661-671, 2005.

30. Bradford MM: A rapid and sensitive method for the quantitation of microgram quantities of protein utilizing the principle of protein-dye binding. Anal Biochem 72: 248-254, 1976.

31. Takano J, Morishita A, Fujihara S, Iwama H, Kokado F, Fujikawa K, Fujita K, Chiyo T, Tadokoro T, Sakamoto T, et al: Galectin-9 suppresses the proliferation of gastric cancer cells in vitro. Oncol Rep 35: 851-860, 2016.

32. D'Incalci M, Colombo T, Ubezio P, Nicoletti I, Giavazzi R, Erba E, Ferrarese L, Meco D, Riccardi R, Sessa C, et al: The combination of yondelis and cisplatin is synergistic against human tumor xenografts. Eur J Cancer 39: 1920-1926, 2003. 
33. Global Burden of Disease Cancer Collaboration; Fitzmaurice $C$, Allen C, Barber RM, Barregard L, Bhutta ZA, Brenner H, Dicker DJ, Chimed-Orchir O, Dandona R, et al: Global, Regional, and National Cancer Incidence, Mortality, years of life lost, years lived with disability, and disability-adjusted life-years for 32 cancer groups, 1990 to 2015: A systematic analysis for the global burden of disease study. JAMA Oncol 3: 524-548, 2017.

34. Mishra J, Drummond J, Quazi SH, Karanki SS, Shaw JJ, Chen B and Kumar N: Prospective of colon cancer treatments and scope for combinatorial approach to enhanced cancer cell apoptosis. Crit Rev Oncol Hematol 86: 232-250, 2013.

35. Li C, Zuo D, Liu T, Yin L, Li C and Wang L: Prognostic and clinicopathological significance of MUC family members in colorectal cancer: A systematic review and meta-analysis. Gastroenterol Res Pract 2019: 2391670, 2019.

36. Nobumoto A, Nagahara K, Oomizu S, Katoh S, Nishi N, Takeshita K, Niki T, Tominaga A, Yamauchi A and Hirashima M: Galectin-9 suppresses tumor metastasis by blocking adhesion to endothelium and extracellular matrices. Glycobiology 18 : 735-744, 2008

37. Wang Y, Sun J, Ma C, Gao W, Song B, Xue H, Chen W, Chen X, Zhang Y, Shao Q, et al: Reduced expression of Galectin-9 contributes to a poor outcome in colon cancer by inhibiting NK cell chemotaxis partially through the Rho/ROCK1 signaling pathway. PLoS One 11: e0152599, 2016.

38. Ahmed D, Eide PW, Eilertsen IA, Danielsen SA, Eknæs M, Hektoen M, Lind GE and Lothe RA: Epigenetic and genetic features of 24 colon cancer cell lines. Oncogenesis 2: e71, 2013.

39. Kramer G, Erdal H, Mertens HJ, Nap M, Mauermann J, Steiner G, Marberger M, Bivén K, Shoshan MC and Linder S: Differentiation between cell death modes using measurements of different soluble forms of extracellular cytokeratin 18. Cancer Res 64: 1751-1756, 2004.

40. Morishita A, Gong $\mathrm{J}$ and Masaki T: Targeting receptor tyrosine kinases in gastric cancer. World J Gastroenterol 20: 4536-4545, 2014

41. Morishita A, Gong J, Nomura T, Yoshida H, Izuishi K, Suzuki Y, Kushida Y, Haba R, D'Armiento J and Masaki T: The use of protein array to identify targetable receptor tyrosine kinases for treatment of human colon cancer. Int J Oncol 37: 829-835, 2010.

42. Aubry A, Galiacy S and Allouche M: Targeting ALK in cancer: Therapeutic potential of proapoptotic peptides. Cancers (Basel) 11: 275, 2019.

43. Azizi R, Salemi Z, Fallahian F and Aghaei M: Inhibition of didscoidin domain receptor 1 reduces epithelial-mesenchymal transition and induce cell-cycle arrest and apoptosis in prostate cancer cell lines. J Cell Physiol 234: 19539-19552, 2019.
44. Nagano K, Yamashita T, Inoue M, Higashisaka K, Yoshioka Y, Abe Y, Mukai Y, Kamada H, Tsutsumi Y and Tsunoda S: Eph receptor A10 has a potential as a target for a prostate cancer therapy. Biochem Biophys Res Commun 450: 545-549, 2014.

45. Yamada S, Kato S, Matsuhisa T, Makonkawkeyoon L, Yoshida M, Chakrabandhu T, Lertprasertsuk N, Suttharat P, Chakrabandhu B, Nishiumi S, et al: Predominant mucosal IL-8 mRNA expression in non-cagA Thais is risk for gastric cancer. World J Gastroenterol 19: 2941-2949, 2013.

46. Lee KH,Bae SH, Lee JL, Hyun MS, Kim SH, Song SK and Kim HS Relationship between urokinase-type plasminogen receptor, interleukin-8 gene expression and clinicopathological features in gastric cancer. Oncology 66: 210-217, 2004.

47. Lee KE, Khoi PN, Xia Y, Park JS, Joo YE, Kim KK, Choi SY and Jung YD: Helicobacter pylori and interleukin-8 in gastric cancer. World J Gastroenterol 19: 8192-8202, 2013.

48. Morishita A and Masaki T: miRNA in hepatocellular carcinoma. Hepatol Res 45: 128-141, 2015.

49. Sun Z, Meng C, Wang S, Zhou N, Guan M, Bai C, Lu S, Han Q and Zhao RC: MicroRNA-1246 enhances migration and invasion through CADM1 in hepatocellular carcinoma. BMC Cancer 14: 616, 2014

50. Xu X, Cao L, Zhang Y,Lian H, Sun Z and Cui Y: MicroRNA-1246 inhibits cell invasion and epithelial mesenchymal transition process by targeting CXCR4 in lung cancer cells. Cancer Biomark 21: 251-260, 2018.

51. Du P, Lai YH, Yao DS, Chen JY and Ding N: Downregulation of microRNA-1246 inhibits tumor growth and promotes apoptosis of cervical cancer cells by targeting thrombospondin-2. Oncol Lett 18: 2491-2499, 2019.

52. Sun LN, Zhi Z, Chen LY, Zhou Q, Li XM, Gan WJ, Chen S, Yang M, Liu Y, Shen T, et al: SIRT1 suppresses colorectal cancer metastasis by transcriptional repression of miR-15b-5p. Cancer Lett 409: 104-115, 2017

53. Dong Y, Zhang N, Zhao S, Chen X, Li F and Tao X: miR-221-3p and $\mathrm{miR}-15 \mathrm{~b}-5 \mathrm{p}$ promote cell proliferation and invasion by targeting Axin2 in liver cancer. Oncol Lett 18: 6491-6500, 2019.

54. Tang T, Yang L, Cao Y, Wang M, Zhang S, Gong Z, Xiong F, He Y, Zhou Y, Liao Q, et al: LncRNA AATBC regulates Pinin to promote metastasis in nasopharyngeal carcinoma. Mol Oncol 14 2251-2270, 2020.

This work is licensed under a Creative Commons

Attribution-NonCommercial-NoDerivatives 4.0

International (CC BY-NC-ND 4.0) License. 